\title{
Zonal Management: Addressing Sustainability Issues in Aquaculture
}

\author{
Ernesto J. Morales ${ }^{1}$, Anton Immink ${ }^{2}$, Pamudi, Linh Nguyen Thanh, and Han Han ${ }^{3}$ \\ ${ }^{1}$ Aquaculture Technical Director, Sustainable Fisheries Partnership \\ ${ }^{2}$ Aquaculture Director, Sustainable Fisheries Partnership \\ ${ }^{3}$ China Blue Sustainability \\ *Email: jack.morales@sustainablefish.org; anton.immink@sustainablefish.org; han.han@chinabluesustainability.org
}

\begin{abstract}
Ernesto J. Morales, Anton Immink, Pamudi, Linh Nguyen Thanh, and Han Han. 2017. Zonal Management: Addressing Sustainability Issues in Aquaculture. Aquacultura Indonesiana, 18 (2): 41-47. Aquaculture industries in general face several sustainability issues as the operations still rely on the quality of available water resources. Most aquaculture systems utilize common water resources in the production as well as discharging effluents from the farm; hence water is still considered as the major factor in spreading diseases in an area where aquaculture production is concentrated. Moreover, most input sources (e.g feeds, seeds and chemicals) in most cases are also similar (or shared) among aquaculture producers in the area. The most common recommended best management practices nowadays, including those from the national and commercial aquaculture standards, limit the requirements in addressing management issues that can be controlled within the farm only and that the outside environment (e.g. rivers and coastal areas) in most cases is overlooked. Producers are commonly advised to improve their individual practices in order to achieve higher production and limiting the occurrence of disease within the farm. The Sustainable Fisheries Partnership (SFP) as an organization that promotes sustainable practices in fisheries and farming, recognizing the cumulative impact of aquaculture on receiving water bodies where aquaculture production is pooled and intensified. Due to the minimal (if not lacking) regulations and coordination among producers on the use of water resources and effluent discharge, sourcing inputs, stocking events, reporting of disease outbreak and the use of drugs and chemicals, the fate of aquaculture as a whole is uncertain. This paper introduces the five pillars of zonal management where scientific information (carrying capacity and epidemiology) are critical as well as the laws and regulations in order to develop better management recommendations that would cover an aquaculture zone. Moreover, this paper provides updates on the different approaches applied in aquaculture zones in China, Indonesia and Thailand in pursuit to a more sustainable practice in aquaculture through zonal management. The approach uses a multistakeholder strategy where key players of the aquaculture industry play a critical role. The paper highlights that there is no strategy that would fit in all aquaculture zones rather would mainly depend on the status of the industry, hence the level of importance and the role that each stakeholder plays may not be the same in all zones.
\end{abstract}

Keywords: Aquaculture certification; Aquaculture improvement project; Best management practices; Cumulative impacts; Zonal management.

\section{Introduction}

Aquaculture plays significant role in global nutrition as it contributes in providing highquality, animal protein and other essential nutrients (Subasinghe et al., 2004; OECD 2010). Based from the latest FAO report, Asia contributed more than $75 \%$ of the global aquaculture production (FAO, 2014); hence in order to sustain global production, the focus of improvement projects should be given more priority to this region. The supply of seafood continues to decline; hence the pressure from aquaculture sector to expand and intensify is increasing. This expansion includes increasing cultivated areas, increasing density for aquaculture installation as well as increasing the demand for inputs (Ross, et. al., 2013). The various sustainability issues associated with aquaculture have been recognized by various sectors including the FAO, the environmental non-government organizations (eNGO), the academia and the national governments where aquaculture is significant. Some of these sustainability issues were also considered by some commercial aquaculture certifications in developing their standard for responsible aquaculture (Corsin et al., 2007). One of the most critical considerations in aquaculture is the water resource and how it can be protected from deteriorating quality due to bad management in the farm effluents. The increase in cultivated water areas, the nutrient loads coming from commercial feeds, organic matter produced from the farm, contaminants from inputs as well as biological factors are some of the main concerns in aquaculture regardless of the scale of production 
(Ross et al., 2013). However, the impacts of these issues are more obvious and magnified as the industry reaches scale (Tilman et al., 2002), not to mention the social issues associated with farming operations. Even more critical to the industry itself, and often to the food safety of consumers, is the management of disease risks within and between farms. In most cases, farms may overlook the importance of biosecurity planning that is appropriate and being implemented (OIE, 2015). Catastrophic disease problem like ISA (infectious salmon anemia) outbreak for salmon in Chile (OECD, 2010) and impacts of on-going new disease emerging with shrimp (e.g. whitespot, yellow head and early mortality syndrome) could be mitigated not only by individual farm biosecurity measures but by stronger coordination, collaboration and joinedup data-sharing and emergency response plans between industry and government (World Bank, 2013). However, the government sector would need extensive scientific information such as carrying capacity analysis in order to develop appropriate policies (Rice, 2014).

\section{The five pillars of zonal management}

Implementing an aquaculture policy or an improvement project has no blueprint (Brugere $e t$ al., 2010) as no two waterbodies are similar. The zonal management needs broader engagement across the seafood industry to bring about change to support the future sustainability of the industry as a whole. There is no fixed procedure in implementing the zonal management concept. However based from past experiences and major catastrophic failures that had happened in salmon industry and the Asian black tiger shrimp ( $P$. monodon) in the mid 90's, SFP considered that effective zonal management should cover five key focus areas in the aquaculture industry (Immink et al., 2017). This would play major role in improving the management structure of an aquaculture zone:

1. Effective regulation based on sound science. Local regulators where the aquaculture zones are located should be enforcing evidence-based policies and based from the environmental condition (Rice, 2014) of the area for scale and location of farms and eventually all resource users will be covered.

2. Active producer organizations guiding the industry towards sustainability. An active producer organization should have developed and implementing code of conduct where members are adhering to for sustainable farming. Each member of the organization should be encouraged to collaborate in order to reduce the environmental and disease risks associated with aquafarming. Moreover, the collection of information on a zonal scale should be initiated or lead by the producer organization in the aquaculture zone.

3. Planning, guidelines for licensing and management of industry development and production should be based on scientific resources such as recent carrying capacity (Rice, 2014) data carried out in the zone; where available field evidences should be utilized to refine or update environmental limits.

4. The use of epidemiology and other science to minimize disease risks during planning operational and emergency phases of the industry. This can be achieve through several management activities such as the development of national and zonal aquatic animal health plan that promotes collaboration among producers

5. A feed strategy based on reducing impact and risk to source fisheries providing fishmeal. The zonal management group should develop guidelines on responsible sourcing of feeds and implementing feeding strategies that considers the nutrient levels of the receiving water bodies.

These projects are part of an on-going program of the Sustainable Fisheries Partnership in the region. The aquaculture improvement projects started promoting zonal management in 2012 , therefore the paper is reporting the work in progress of four aquaculture improvement projects initiated by the organization in the region. The objective of the aquaculture improvement project is to promote sustainable farming practices that address the cumulative impacts of aquaculture through zonal management approach. The main focus of the improvement projects has been around strengthening the local industry associations and producer groups to engage in sustainable management and development; reducing local environmental impacts and manages disease risks.

\section{Materials and Methods}

SFP provided assistance to the industry groups in the three sites for implementing the different activities of the aquaculture improvement but also lead the group to be more independent and manage the activities as part of their ongoing work programs. Ultimately, it is expected for all three sites to be able to achieve a zonal management program that is workable and that key stakeholders were identified and participating 
by the end of the program. As this is an action research type, the implementation of the program was not identical as activities depended on the situation on the ground. As a result, the case studies have faced different challenges at different stages of the program. Comparison among these approaches can be done to determine the strength and weaknesses of each approaches, however, it would be more beneficial to combine learnings and experiences to give a more complete picture. Note that the main goal of this program is not to compare approaches but to develop better strategies that would ensure sustainability of zonal management activities.

\section{Determining zones for zonal management}

The zone for aquaculture improvement projects is not limited to the physical boundaries only, which is typical to the traditional aquaculture zone or cluster programs of national governments (Huchzermeyer and Bondad-Reantaso, 2017) in achieving aquaculture development. However, the key factor for zonal management, as implemented by SFP, is the availability of a zonal management plan that promotes coordination and collaboration amongst members of the improvement project (Immink and Clausen, 2017). The FAO has a similar concept where it was labeled as area management approach to aquaculture (Immink, et. al., 2017). These two concepts have a lot of similarities particularly in improving the sector's management structure. A zonal management area might be a river or coastal area where different users of the resource cooperate in planning and implementing rules and regulations regarding the utilization of such water body (MRC, 2005) or a group of farmers in one administrative region but supplying to processing plants supplying a particular market. For zoning relating to the control of diseases, FAO considers zonation described by OIE as a reliable system for disease control and surveillance (Subasinghe et al., 2004). In all cases, operators in an aquaculture zone should follow a management plan that coordinates actions beyond their individual farms.

Table 1. Description of aquaculture zones under the SFP aquaculture improvement projects

\begin{tabular}{|c|c|c|c|c|}
\hline $\begin{array}{l}\text { Aquaculture } \\
\text { zone }\end{array}$ & Site Description & Species & Key players & Drivers /Goal \\
\hline Hainan Tilapia & $\begin{array}{l}\text { Mixture of scale of production } \\
\text { (large, medium, small), farms are } \\
\text { not connected, intensive and semi } \\
\text { intensive management }\end{array}$ & Tilapia & $\begin{array}{l}\text { Local } \\
\text { producer } \\
\text { association, } \\
\text { local NGO }\end{array}$ & Retailer/certification \\
\hline $\begin{array}{l}\text { East Java } \\
\text { Shrimp }\end{array}$ & $\begin{array}{l}\text { Mainly medium and small scale } \\
\text { producers, sharing the same } \\
\text { coastal water, traditional and semi } \\
\text { intensive management }\end{array}$ & $\begin{array}{l}\text { Shrimp } \\
\text { (Pacific } \\
\text { white leg } \\
\text { shrimp) }\end{array}$ & Shrimp Club & $\begin{array}{l}\text { Producer organization/ } \\
\text { minimized disease, } \\
\text { improved farming } \\
\text { practices and increased } \\
\text { production }\end{array}$ \\
\hline $\begin{array}{l}\text { Vietnam/ } \\
\text { Thailand }\end{array}$ & $\begin{array}{l}\text { Mainly medium and small scale } \\
\text { producers, sharing the same } \\
\text { coastal water, semi intensive and } \\
\text { intensive management }\end{array}$ & $\begin{array}{l}\text { Shrimp } \\
\text { (Pacific } \\
\text { whiteleg } \\
\text { shrimp) }\end{array}$ & $\begin{array}{l}\text { Local } \\
\text { Department/ } \\
\text { project staff }\end{array}$ & $\begin{array}{l}\text { Donor and local } \\
\text { organization/ strengthen } \\
\text { groups and minimize } \\
\text { disease }\end{array}$ \\
\hline
\end{tabular}

\section{SFP's Approach}

SFP's traditional approach usually starts with a supply chain mapping. This step will provide the organization a broader understanding of the industry from the production (the different sources, producers of aquaculture products) up to the end of the supply chain (retailers and target consumers). Through the market analysis, key stakeholders (producers, input providers, suppliers/buyers) and potential implementor of the aquaculture improvement project will be identified. However, this initial step may not always be followed as some aquaculture zones have already established the information and key stakeholders have been identified as well as their potential role have been recognized. In this case, SFP's role will be more on strengthening the capacity of the identified key stakeholders in initiating the improvement program and creating a platform for the other members to discuss. The participation of stakeholders from different agencies is also essential (Staples and FungeSmith, 2009) to help producers to implement improved management practices.

\section{Results}

The output and findings of the implemented zonal management in the selected areas in the region illustrate the different approaches of zonal management that can be 
applied in a particular aquaculture zone as well as the current status of the program. Some lessons learned and challenges in the implementation of the program are also highlighted in this section. The three major aquaculture improvement programs that were implemented in the region are; China for Tilapia farming, Indonesia for shrimp farming and Thailand and Vietnam for shrimp farming as well. The industry situation, the relationship and composition of the stakeholders and the drivers of aquaculture improvement projects are different in these three areas, which resulted to variation in the approaches applied as well as the results. These different approaches may not be followed strictly, however it may provide guidance to other implementor of an improvement project.

\section{Hainan Tilapia Aquaculture Improvement Project}

The initial engagement of SFP with the tilapia stakeholders was through the retailer partner with a focus on individual farm level certification. However, the engagement was developed into a much broader scope beyond certification when it became evident that there are much bigger issues than individual farm improvements and no one is addressing them. A local producers association was formed including key input supplier and processing plant operators to cover issues in the whole supply chain. A study on the environmental impacts of the tilapia farming was carried out which lead to a closer relationship with the implementor and the local producers. Through regular communication, the key players in the local industry understood the shared risks the industry is facing if the existing individual and no coordination amongst producers will continue. The newly formed association of producers realized the importance of developing a unified voice to protect the industry and create product image that reflects the responsible practices of the producers in the aquaculture zone. The local association is now called the Hainan Tilapia Sustainability Alliance (HTSA); which handles issues in quality seed, responsible sourcing of feeds, technical support, improved farming and processing practices. The members of the association are now fully engaged in the idea of collaboration among other producers, practicing more environmentally friendly practices that are socially and economically beneficial. The association is now using this concept to promote and created brand to their product. Though the implementation of the zonal management in Hainan looks smooth and easy, where code of good practice was developed and followed by all members of the associations, challenges still remain in building effective zonal management into the regulatory structure in Hainan and even on a national level. The members' interest in the approach is still being affected by the trend in market. The national and local regulators process in developing regulations to adopt the zonal management concept takes longer than expected and several factors need to be considered such as producers' interest, market trend as well as demand.

\section{East Java Shrimp AIP}

Initial engagement of SFP with the Banyuwangi shrimp producers started from gap analysis for shrimp standard way back in 2010 . The engagement was further continued when a shrimp buyer requested a review of potential farms in the province to meet international certification standard. In order to enable smallscale producers in this region to meet the requirements, several activities needed to be done to help the farms to improve their farming practices. These activities were done in collaboration with local shrimp club, the Shrimp Club of Indonesia (Banyuwangi) and other international NGOs. SFP worked with the members of the shrimp club in Banyuwangi to promote zonal management with particular focus on limiting the occurrence of disease. The Muncar area in Banyuwangi is ideal for zonal management as shrimp farms are almost similar in terms of management practices, all are interconnected and sharing the same water resource. Through this program a responsible person was identified to help the club develop a zonal management plan to improve the farming system and eventually mitigate the spread of disease.

The zonal aquaculture improvement project site in Banyuwangi serves as a demonstration of how more advanced shrimp operators who have the capacity to control disease issues within their farms but understand the potential of being impacted by other producers in the zone; hence are interested and open to come together to support the information campaign and support access to resources to minimize the risks of disease outbreak. The zonal management approach has created a platform and increased linkages with local government agencies as well 
as local organizations and key industry stakeholder to understand the value of science in developing regulations and management plans such as carrying capacity and epidemiology studies. The department of fisheries in Indonesia and the key stakeholders are already implementing multi stakeholder roundtable process, which is the core of effective zonal management. The active participation of the ministry in Indonesia had helped the implementation of the zonal management as a success so far. The local agency of the ministry in Banyuwangi has extended their technical support to the member of the producers group. Furthermore, representative of group were invited to participate in local and national meetings for improving aquaculture industry in the country.

\section{Aquaculture Improvement Projects in Vietnam and Thailand}

Unlike the approaches in China and Indonesia where the industry and local government initiated and strongly supported the proposed improvements, the improvement projects in Vietnam and Thailand were initiated through donor initiative which mainly focused on how small scale operators can improve their farming system using the recommended better management practices and limit the negative impact to the environment through zonal management approach. The donor's interest was not in line with the interest and focus of the industry as well as government agency. Both the industry and the government agency in these sites were more focused on management activities and intervention that would directly address the emerging problem that badly damaged the industry; which are diseases and low production. The lack of industy support and different priorities of government made the progress of zonal management in these sites slower than Hainan, China and East Java, Indonesia AIPs. The initial projects have now been replaced by more focused projects working on specific supplychains. There are several lessons learned with Hainan and East Java AIP that implementor in Vietnam and Thailand can adopt, particularly in bringing producers together to tackle common risks like disease management. Perhaps the management level (semi intensive and intensive production) of producers in Thailand and Vietnam as well as the practices in water management (closed system) made it more difficult to implement the zonal management approach in these areas, as producers tend to be isolated. Determining the market incentive around consistent purchasing rather than specific additional price has been a key component of these projects. Once these individual supply chain projects are embedded the lessons will be scaled up locally with shrimp clubs to cover the broader zone of producers through coordinated management.

\section{Conclusion}

The sustainability issues in aquaculture are high when cumulative impacts are being overlooked. Individual farm management may have solved the on farm issues but potentially contributing to the deterioration of the outside environment through the accumulation of wastes, pathogens and other microorganisms in the receiving waterbodies. The zonal management through coordinated farming practices and appropriate laws and regulations on the otherhand addresses issues occurring in the natural environment brought by farming activities. There are several benefits (immediate and long-term) of implementing zonal management in an area where aquaculture production is concentrated. Some of the immediate benefits of zonal management that were observed so far from this program are coordination among users on the intake and discharge of water which might address or mitigate the spread of new diseases and transparency on the management practices. On the otherhand; the long term impact of zonal management foreseen in this project are broader awareness of policy makers for future development of regulations in proper siting and licensing aquaculture establishments; the use of drugs and chemicals; maintaining the good quality of natural environment surrounding the farms; establishment of traceability system and sharing of information among producers within the zone.

Through zonal management, key stakeholders of an aquaculture zone on an area management can be engaged more directly in the development of appropriate regulations and implementation of management actions that would address cumulative issues in farming aquatic animals. However, working together seems to be one of the major challenges in zonal management since individual intenstions are in most cases different. Great effort is needed to 
change the paradigm of most producers to be more open and cooperative. Moreover, even nonaquafarmer stakeholder that are using or benefiting from the water resource can also be engaged in this management scheme to ensure a more holistic approach where all potential contributors on the improvement of the natural environment are being managed.

The application of zonal management approach is unique in every aquaculture zone as it is influenced by several factors. Some of the factors that may affect the implementation of the approach are; the composition and capacity of the group of producers, environmental situation, status of the industry and its associated risks (production, health, and market), available support from the whole industry/supply chain, as well as the interests of other industry/sector utilizing the same resources. In Asia, where the aquafarming industry is considered a private operation with lesser obligation outside the farm and widely dispersed, the implementation of zonal management approach is going to remain a challenge. The lack or weakness of available regulations that address or provide guidance to aquaculture producers and managers the importance of maintaining the common resources or at least practice coordination among neighboring farms also contribute to the challenges of implementing such management approach.

Though the approach for zonal management is unique for specific location and group of stakeholders, critical components should be similar though details remain to be site and species specific. Some of the key outputs are the development of code of good practice for sustainable production, public reporting of management strategies, as well as the zonal management workplan. These are the main indicators where a specific zonal management is progressing or stalled. The development and implementation of these outputs depends on the dynamic of the group where the buyer representative from the group plays a critical role.

Currently, global seafood buyers are becoming more and more aware on the severity of the impacts of aquaculture in the natural environment and eventually to the global supply of seafood; hence some of these buyers have considered this in their procurement policies. For example Walmart, one of the biggest seafood retailers globally, publicly announced that they will only be sourcing seafood that are sustainably produced or caught, either certified or coming from an improvement project. A number of seafood buyers are now engaged with their suppliers and are starting to practice the zonal management concept. It is envisaged that more seafood buyers and key stakeholders will support improvement programs such as zonal management to ensure a more sustainable supply of seafood globally. The zonal management implementor or drivers should seek support from the global seafood buyers not only through assistance in the implementation but also recognition of the products and increasing the awareness of the consumers.

The role of regulators is critical in the implementation and continuity of the zonal management in aquaculture region. Reviewing and developing regulations to support activities of zonal management should be done to lessen the challenges that implementors are facing in aquaculture improvement projects.

\section{Acknowledgement}

SFP would like to thank the Packard Foundation and the USAID under the MARKET project that funded this phase of the project and IDH and the Walmart Foundation for their follow-on support. The local producers, processing plants and seafood buyers who participated in the development of the project and are still believing the value of the program to the seafood sector should also be recognized.

\section{References}

Brugère, C., N. Ridler, G. Haylor, G. Macfadyen and N. Hishamunda. 2010. Aquaculture planning, policy formulation and implementation for sustainable development. FAO Fisheries and Aquaculture Technical Paper. No. 542. Rome, FAO. 70 pp. (also available at www.fao.org/docrep/012/i1601e/ i1601e00.pdf).

Corsin, F., S. Funge-Smith, and J. Clausen. 2007. A qualitative assessment of standards and certification schemes applicable to aquaculture in the Asia-Pacific region. RAP Publication 2007/25, 98pp.

FAO. 2014. The State of World Fisheries and Aquaculture. Opportunities and challenges, $243 \mathrm{pp}$.

Huchzermeyer, K.D.A., and M.G. BondadReantaso. 2017. Biosecurity, zoning and compartments, infected zones, disease-free zones. In: J. Aguilar-Manjarrez, D. Soto, and R. Brummett (Eds.). Aquaculture zoning, site selection and area management under the ecosystem approach to aquaculture. Full document, pp 87-94. Report ACS113536. 
Rome, FAO, and World Bank Group. Washington DC, 395 pp.

Immink, A. and J. Clausen. 2017. Aquaculture Certification and Zonal Management. In: J. Aguilar-Manjarrez, D. Soto, and R. Brummett (Eds.). Aquaculture zoning, site selection and area management under the ecosystem approach to aquaculture. Full document, pp 87-94. Report ACS113536. Rome, FAO, and World Bank Group. Washington DC, 395 pp.

Immink, A., H. Han, Pamudi, and J. Morales. 2017. Zonal aquculture management in China and Indonesia. In: J. AguilarManjarrez, D. Soto, and R. Brummett (Eds.). Aquaculture zoning, site selection and area management under the ecosystem approach to aquaculture. Full document, pp. 198-221. Report ACS113536. Rome, FAO, and World Bank Group, Washington, DC. 395 pp.

MRC. 2005. Overview of the Hydrology of the Mekong Basin. Mekong River Commission, Vientiane, Laos.

OECD. 2010. Advancing the aquaculture agenda: Workshop proceedings. Organization for Economic Cooperation and Development, OECD Publishing, Paris, France.

OIE. 2015. Aquatic Animal Health Code. Updated annually at http://www.oie.int/en/international -standard-setting/aquatic-code/.
Rice, M.A. 2014. Extension programming in support of public policy for the management of aquaculture in common water bodies. Aquacultura Indonesiana, 15 (1) : 26-31.

Ross, L.G., T.C. Telfer, L. Falconer, D. Soto, and J. Aguilar-Manjarrez. 2013. Site selection and carrying capacities for inland and coastal aquculture. FAO/Institute of Aquaculture, University of Stirling, Expert Workshop, 6-8 December 2010. Stirling, the United Kingdom of Great Britain and Northern Ireland. FAO Fisheries and Aquculture Proceedings No. 21. Rome, FAO. 46 pp.

Staples, D. and S. Funge-Smith. 2009. Ecosystem approach to fisheries and aquaculture: Implementing the FAO Code of Conduct for Responsible Fisheries. FAO Regional Office for Asia and the Pacific, Bangkok, Thailand. RAP Publication 2009/11, 48pp.

Subasinghe, R.P., S.E. McGladdery, and B.J. Hill. 2004. Surveillance and zoning for aquatic animals diseases. FAO Fisheries Technical Paper. No. 451. FAO, Rome, 73pp.

Tilman, D., K.G. Cassman, P.A. Matson, R. Naylor, and S. Polasky. 2002. Agricultural sustainability and intensive production practices. Nature, 418:671-677.

World Bank. 2013. Growing aquaculture in sustainable ecosystems. Agriculture and Environmental Services. 